\title{
外リンパ瘦の臨床像
}

一神経耳科学的所見亡予後について一

五十嵐秀一・小出 千秋・藤岡 治

猪股 茂樹・北村 哲也・中野 雄一

\section{Perilymph Fistula}

-Otoneurological Examination and Prognosis-

Syuichi Igarashi, Chiaki Koide, Osamu Fujioka,

Shigeki Inomata, Tetsuya Kitamura and Yuichi Nakano

(Niigata University)

Of 12 patients with perilymph fistula, 10 (83\%) had cochlear symptoms, $6(50 \%)$ had vestibular symptoms, and $4(33 \%)$ had both. Vestibular function tests revealed direction-fixed positional nystagmus in 9 patients $(75 \%)$, canal paresis (CP) in $6(50 \%)$ and Hennebert's sign in one $(8 \%)$. There was a wide variety of type and severity of hearing loss.

The outcome of the vestibular symptoms was quite good. Eleven patients (91\%) were cured, but positional nystagmus and a positive Mann's test tended to persist for a long time, and CP did not improve. The stepping test was apt to become negative. Improvement of hearing was recorded in only $50 \%$. Five patients underwent surgery, but there was no relationship between the improvement of hearing and operation.

Key words: perilymph fistula, otoneurological examination, prognosis

はじめに

外リンパ瘻では蝸牛症状と前庭症状の両者を 伴うことが多いが，蝸牛症状のみ，前庭症状の みがみられる場合，さらに silent fistula の例む 報告されている。 また内耳障害（特に聴力障 害）の予後は，症例により著しく異なる．われ われは, 外リンパ瘻の初発症状と神経耳科学的 な所見をまとめ，予後との関連につき検討を加 えた。
対象

対象は新潟大学耳鼻咽喉科において1984年 1 月から1988年 4 月までの 4 年 4 力月に経験した 外リンパ瘦 12 例（13耳）である。いずれも診断 は厚生省特定研究急性高度難聴班の診断基準に よった，性別は男性 5 例，女性 7 例. 年齢は 23 歳から75歳で平均年歯は 44.5 歳であった. 発症 から受診までの期間は 4 日〜 2 力月半と症例に よりさまざまであった。 


\section{結果}

1. 原因と発症時の症状および患側 原因は中耳，内耳，脳春䯣圧の変化をきたす あの11例 (91.7\%)，不明 1 例であった。

発症時の症状は難聴が10例 (83.3\%) と最む 多く, ついでめまい 6 例（回転性 4 例, 浮動感 2 例), 耳鳴 4 例の順にみられた. 明確な pop 音は認められなかった。 患側は右側 7 例, 左側 4 例で両側が 1 例みられた。手術を施行したも のは 5 例で, 瘻孔の部位は卵円空 2 例, 正円空 2 例, 瘻孔不明 1 例であった。側頭筋筋膜また は areolar tissue にて瘻孔を閉鎖した(表 1 ).

2. 神経耳科学的検査所見とその推移

1) 平衡機能検査所見

初診時の $\mathrm{ENG}$ 検査では，方向固定性頭位眼 振が 9 例 $(75 \%)$ と最あ多くみられ，ついで $\mathrm{CP}$ が 6 例 (50\%) にみられた. Hennebert 症 候を認めたのは1例のみであった. Mann 検査

表 1 原因, 患側, 初発症状〔耳]例数（\%)

\begin{tabular}{|c|c|c|}
\hline \multirow[t]{9}{*}{ 原 因 } & $\begin{array}{l}\text { 中耳, 内耳, 脳脊䯣圧の } \\
\text { 変化をきたすもの }\end{array}$ & $(91.7)$ \\
\hline & (鼻かみ & 4 \\
\hline & 介達性鼓膜外傷 & 2 \\
\hline & 直達性鼓膜外傷 & 1 \\
\hline & 笛ふき & 1 \\
\hline & スキューバダイビング & 1 \\
\hline & 飛行機の着陸時 & 1 \\
\hline & 力仕事 & 1 \\
\hline & 不明 & $1(8.3)$ \\
\hline \multirow[t]{6}{*}{ 初発症状 } & 難聴 & $10(83.3)$ \\
\hline & めまい & $6(50.0)$ \\
\hline & 耳鳴 & $4(33.3)$ \\
\hline & 耳漏 & $2(16.7)$ \\
\hline & 耳閉感 & $1(8.3)$ \\
\hline & POP 音 & $0(0.0)$ \\
\hline \multirow[t]{3}{*}{ 患 側 } & 右側 & $7(58.3)$ \\
\hline & 左側 & $4(33.3)$ \\
\hline & 両側 & $1(8.3)$ \\
\hline \multirow[t]{4}{*}{ 手術例 } & 確認 & {$[4](80.0)$} \\
\hline & 卵円空 & 2 \\
\hline & 正円空 & 2 \\
\hline & 不明 & {$[1](20.0)$} \\
\hline
\end{tabular}

は 5 例 $(42 \%)$ が陽性で，足踏検査は 7 例（58 \%) が陽性であった（表 2$)$.

検査結果の推移をみると，図１亿示すように 方向固定性眼振は軽快した例もみられるが初診 時めまいを訴えた例では長期にわたり ENG下 に眼振が持続する傾向がみられた. しかし眼振 はみられても自覚的にはめまいは改善のみられ た例が多かった，CPについては，自覚的に初 発症状としてめまいがなくても CP のみられる 例や，めまいがあっても CP のみられない例が みられた。 2 回以上温度眼振検査を施行した例 は2 例のみであるが， $\mathrm{CP}$ の改善はみられなか った. Mann 検査ではめまいを有する症例で陽 性率が高く，また長期にわたり陽性を示す傾向 がみられた。一方，足踏検査では数週間から数 力月で軽快する傾向がみられた。

\section{2. 聴力検査所見}

混合難聴 2 耳，感音難聴11耳であったが，難 聴の程度はさまざまであった（平均聴力レベル 56. $1 \mathrm{~dB}$ ). また聴力型も水平型 4 耳 (33.3\%), 山型 3 耳, 高域漸傾型 3 耳, 低音障害型 3 耳之

\section{表 2 神経耳科学的所見 [耳] 例数（\%)}

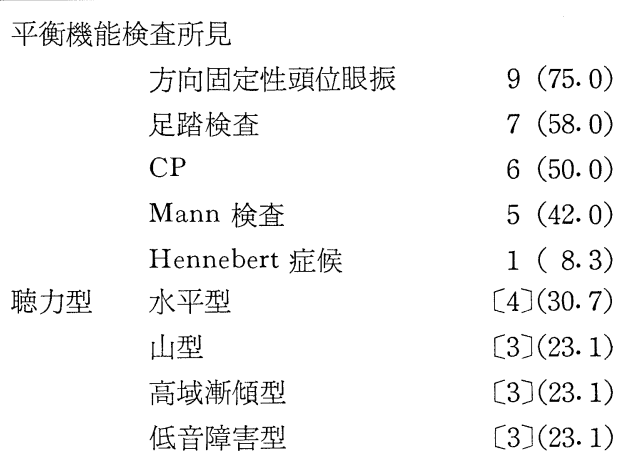

表 3 めまいと聴力障害の予後 [耳] 例数（\%)

\begin{tabular}{llr}
\hline めまいの改善 & あり & $11(91.7)$ \\
& なし & $1(8.3)$ \\
聴力改善 & あり & {$[6](46.1)$} \\
& 不変 & {$[2](15.4)$} \\
& 悪化 & $\lceil 2](15.4)$ \\
& 不明 & {$[3](23.1)$}
\end{tabular}


さまざまであり，特に一定の傾向はみられなか った（表 2)。聴力の予後は，ほぼ不変のもの から改善した例，悪化例とさまざまで，最終聴 力は全体としては平均聴力レベル $49.3 \mathrm{~dB}$ と やや改善傾向がみられたが，推計学的には有意 差を認めず．また手術例と手術を行わなかった 例の聴力改善についても有意差を認めなかった (T-test, $\mathrm{P}<0.05$ ) (図 2).

3. めまいと聴力障害の予後

めまいの有無は自覚症状により判定した。聴 力に関しては厚生省突発性難聴班会議による聴 力回復の判定基準に準じた.

その結果，めまいに関しては 1 例を除き予後 良好（91.7\%）であった。一方，聴力改善は6 耳（46.1\%）にのみ認められた。不変は 2 耳, 悪化 2 耳，不明 3 耳であった（表 3 ）。

\section{考察}

外リンパ瘻は1968年, Simmons ${ }^{1)}, \mathrm{Fee}^{2)}$ によ り報告されて以来，多くの発表がみられるが臨 床所見や検査所見が症例により多彩であり，そ の本質的な診断や特徵的な所見を見いだすには

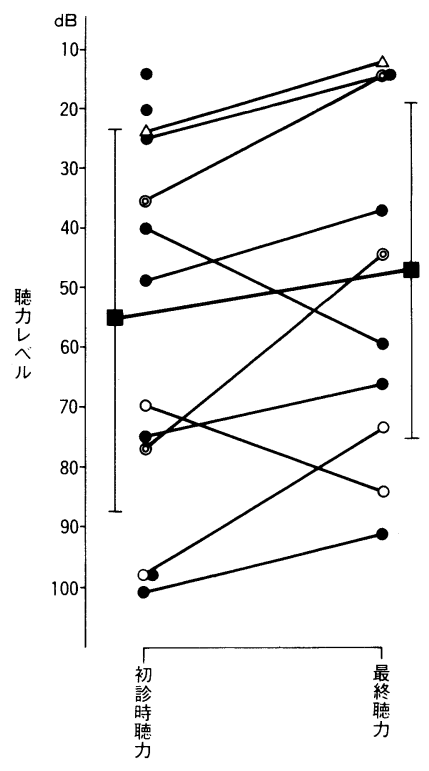

図 2 初診時聴力と最終聴力の比較 (平均㯖力レベル)

-一—手術未施行例

○一 ○ 正円空破裂例

○一○ 卵円空破裂例

$\triangle-\triangle$ 瘦孔不明例

-一全症例の聴カレベル平均
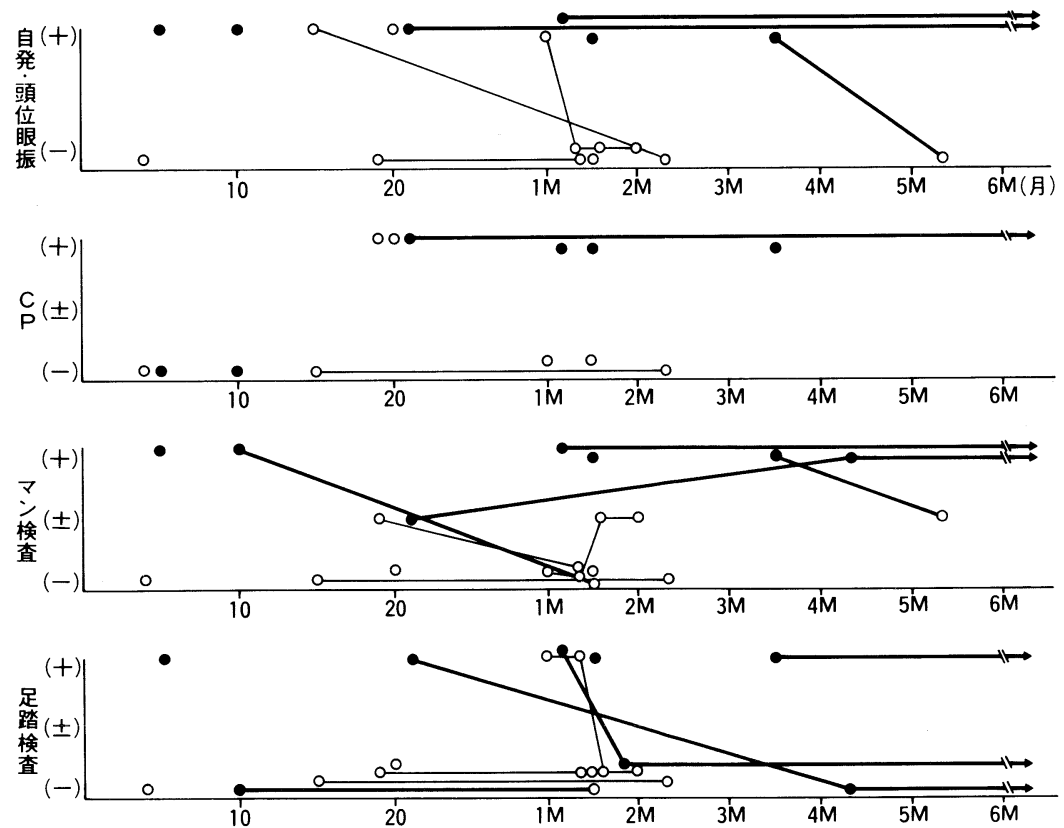

図 1 平衡機能検査の推移

○めまいあり ○めまいなし 
多数の症例を統計的に分析する必要がある。わ れわれの経験した症例はわずか12例であり，乙 れであって統計的に外リンパ瘻の特徵を論ずる ことはできない，多数の文献をもとにその臨床 像，検査所見の把握を試みた論文は，本邦では 寺山ら ${ }^{3)}$, 深谷ら ${ }^{4)}$ の報告がある。 また最近 Seltzer ${ }^{5)}$, Shelton ら ${ }^{6)}$ があいついで外リンパ
瘻の手術例の分析結果を報告している. Seltzer は214例の手術例中外リンパ瘻が確認された 91 例（95耳）につき詳細な検討を行っており，

Shelton らは外リンパ瘻を疑い手術を施行した 65例につき検討を行っている。 これらは外リン パ瘻の特徴を統計的に分析するのに十分な例数 と考えられる。乙の 2 つの報告と今回のわれわ

表 4 外リンパ瘻報告例

\begin{tabular}{|c|c|c|c|c|c|}
\hline & 著者ら & 深 谷 ら4) & Seltzer $ら^{5)}$ & Shelton $ら^{6)}$ & 備 \\
\hline $\begin{array}{ll}\text { 例 } & \text { 数 } \\
\text { 年 } & \text { 䛧令 }\end{array}$ & $\begin{array}{c}\text { 12例（13耳） } \\
23 \sim 75 \text { 歳( } 44.5 \text { 歳) }\end{array}$ & 115例 & $\begin{array}{c}91 \text { 例95耳(手術例) } \\
2 \sim 80 \text { 歳 }\end{array}$ & $\begin{array}{c}\text { 65例 } \\
2.5 \sim 78 \text { 歳 }(40 \text { 歳) }\end{array}$ & （）平均 \\
\hline 性 & 男性 5, 女性 7 & 男性53, 女性44 & 男性45, 女性46 & 男性 $1 / 3$, 女性 $2 / 3$ & \\
\hline 患側と部位 & $\begin{array}{c}\text { 右 } 7 \text {, 左 } 4 \text {, 両 } 1 \\
\text { O } 3, \text { R } 2\end{array}$ & $\begin{array}{l}\text { 右 } 37, \text { 左 } 46, \text { 両 } 6 \\
\text { O } 35, \text { R } 39, \text { B } 7\end{array}$ & $\begin{array}{c}? \\
\text { O52, R34, B } 9\end{array}$ & $\begin{array}{c}\text { 右 }=\text { 左 } \\
\text { O } 21, \text { R 9, B } 3\end{array}$ & $\begin{array}{l}\text { O卵円空 R 正円 } \\
\text { 空 } B \text { 両側 }\end{array}$ \\
\hline 因 & $\begin{array}{ll}\text { 圧外傷 } & 9 \\
\text { 外傷 } & 2 \\
\text { 特発性 } & 1\end{array}$ & $\begin{array}{l}\text { 圧外傷 } 22 \\
\text { 特発性 } 75\end{array}$ & $\begin{array}{ll}\text { 手術 } & 24 \\
\text { 外傷 } & 21 \\
\text { 特発性 } & 22 \\
\text { その他 } & 24\end{array}$ & $\begin{array}{lr}\text { 圧外傷 } & 13 \\
\text { 外傷 } & 16 \\
\text { 特発性 } & 33 \\
\text { 手術 } & 3\end{array}$ & \\
\hline 臨床症状 & $\begin{array}{lr}\text { 難聴 } & 11 \\
\text { めまい } & 6 \\
\text { 耳鳴 } & 4 \\
\text { 耳漏 } & 2 \\
\text { 耳閉 } & 1 \\
\text { POP } & 0\end{array}$ & $\begin{array}{ll}\text { 難聴 } & (93.1) \\
\text { めまい } & (69.0) \\
\text { 耳鳴 } & (43.7)\end{array}$ & $\begin{array}{lll}\text { 難聴 } & 80(84) \\
\text { めまい } & 73(80) \\
\text { 耳鳴 } & 58(63)\end{array}$ & $\begin{array}{ll}\text { めまい } & 47 \\
\text { 難聴 } & 18\end{array}$ & ( ) $\%$ \\
\hline $\begin{array}{l}\text { めいの性 } \\
\text { 状亡検査所 } \\
\text { 見 }\end{array}$ & $\begin{array}{ll}\text { 回転性 } \quad 4 \\
\text { 浮動感 } \quad 2 \\
\text { 自発頭位眼振 } & 9 \\
\mathrm{CP} & 6 \\
\text { Henne } & 1\end{array}$ & $\begin{array}{l}\text { 回転性 }(80.0) \\
\text { 浮動感 }(16.6) \\
\text { 頭位変換 }(3.3) \\
\text { Henne, CP>自発 } \\
\text { 頭位 }\end{array}$ & $\begin{array}{ll}\text { 回転性 } & 13 \\
\text { 平障十浮 } & 15 \\
\text { 回十平障 } & 14 \\
\text { Henne } & 22 \\
\text { めまいなし18 }\end{array}$ & 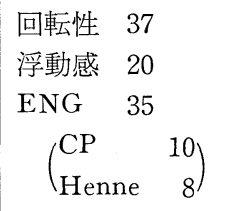 & $\begin{array}{l}\text { ( ) } \% \\
\text { 平障 : 平衡障害 } \\
\text { Henne : } \\
\text { Hennebert 症候 }\end{array}$ \\
\hline 聴 力 型 & $\begin{array}{ll}\text { 水平型 } & 4 \\
\text { 山型 } & 3 \\
\text { 高域漸傾 } & 2 \\
\text { 低音障害 } & 2 \\
\text { 正常 } & 1\end{array}$ & $\begin{array}{lr}\text { 水平型 } & 10 \\
\text { 高域漸傾 } & 6 \\
\text { 谷型 } & 5 \\
\text { 低音障害 } & 4\end{array}$ & $\begin{array}{lr}\text { 変動性 } & 28 \\
\text { 高度難聴 } & 19 \\
\text { 高域漸傾 } & 6 \\
\text { 低音障害 } & 5 \\
\text { 正常 } & 15 \\
\text { その他 } & 22\end{array}$ & $\begin{array}{lr}\text { 高域漸傾 } & 32 \\
\text { 低音障害 } & 5 \\
\text { 水平型 } & 6 \\
\text { 分類不能 } & 2 \\
\text { 正常 } & 20\end{array}$ & \\
\hline めまいの推 & 91.1\%が改善 & ほぼ完全消失？ & 94\%が改善 & & \\
\hline 聴力の推移 & $\begin{array}{l}\text { 改善 } \\
\text { 不変 } \\
\text { 悪化 }\end{array}$ & $\begin{array}{l}\text { 不変 } \quad 34 \\
\text { 谷型, 低音障害型 } \\
\text { で聴力改善良好 }\end{array}$ & $\begin{array}{l}\text { 改善 } 32(49) \\
\text { 固定 } 26(40) \\
\text { 悪化 } 7 \text {, 不明 } 15\end{array}$ & $\begin{array}{l}\text { 手術例中の } 64 \% \\
\text { が軽快 }\end{array}$ & ( ) $\%$ \\
\hline
\end{tabular}


れの症例，および梁谷らの報告の比較検討を行 った．検討項目は以下の 9 項目，すなわち(1)年 齢, (2)性別, (3)患側, (4)原因, (5)臨床症状, (6) めまいの性状と検查所見，(7)聴力型，(8)めまい の予後, (9)聴力の予後である(表 4).

年齢：年稌について記載のあるものは Shelton らの報告で， 2.5 歳〜 78歳ときわめて年齢 幅が広い. 平均年齢は40歳で，乙れはわれわれ の報告とほぼ一致している. Seltzer らの報告あ 年齢幅の広いことに関しては同様であった，外 リンパ瘻は小児から老人まで起とりうる疾患と いえる.

性 : Shelton らは女性が男性の 2 倍多かった と報告しているが, Seltzer らの報告ではほぼ同 数, 深谷らの報告では若干男性に多く，われわ れの結果ではやや女性に多かった，総じてはっ きりした男女差はないように思われる。

患側：左右差については, Shelton らは左右 同数，深谷らはやや左側に多く，われわれの結 果は右側にやや多い。中野ら ${ }^{7)}$ は圧外傷の場合， 感染の有無や乳突蜂巣の左右差に上り易受傷性 に左右差が生ずる可能性を推論している.

卵円空，正円空の別では, Seltzer ら, Shelton らは卵円空に多いと報告し，深谷らは正円空に 多いという．Seltzer らの報告ではアブミ骨手 術，ossiculoplasty，乳突削開術，人工内耳埋め 込み術などの手術例が含まれており, Shelton らの報告例にも 3 例手術例が含まれている。 こ のようなととから卵円空に外リンパ瘻が多い一 因とも考えられるが，深谷らによると特発性や 圧外傷による場合は正円空に多く，特に圧外傷 ではほとんどが正円空であるという.

原因：報告によりさまざまだが，主なものは 外傷 (含圧外傷), 手術, 特発性に大別される. Shelton ら，深谷らの報告には特発性の外リン パ瘻が多く，寺山の報告では圧外傷が多い. われわれの結果も圧外傷が最も多かった。手 術による外リンパ瘻については Seltzer ら, Shelton らの報告には含まれているが，本邦で は手術による外リンパ瘻は統計的に除外する場
合があり，詳細は不明な点がある．要は圧外傷 でも特発性でも出現するが，その出現頻度に目 だった差はないように思われる。

臨床症状 : どの報告屯大差はなく, 難聴 $>め$ まい>耳鳴の順に多くみられた. Shelton らの み，めまい>難聴の順であるが，他の 3 者の報 告からは，やはり蝸牛症状が前庭症状より多く みられるといえる. 臨木的に外リンパ瘻に特徴 的であるといわれる pop 音については，記載 がないか，あってあ頻度は低く，それほど多い あのではないように思われる，ただし pop 音 が一過性にあってあ自覚的に気づかなかった場 合や，難聴，耳鳴が高度で気づかない不顕性の 場合むありうるため，実際には論文に記載され る頻度より多い可能性はあると考えられる.

めまいの性状と検査所見：報告により若干異 なるが，お拈むね回転性めまい>浮動感の順に みられ, 回転性めまいは浮動感の 2 倍以上の頻 度である．乙れは急激に末梢前庭が障害される ことによるものと思われる. 検査所見では, Shelton らの報告によれば, CP が30\%程度にみ られることになる。われわれの結果であ $50 \%$ に みられており，かなり高頻度にみられるようで ある. Hennebert 症候は, Shelton ら, Seltzer ら の報告はともに20\%強の頻度である。しかし， 深谷ら ${ }^{8)}$ は自験例で Hennebert 症候を認めて おらず，暁ら 9 の報告でも外傷性外リンパ瘦で Hennebert 症候の検査を行った 19 例中, 典型 的な陽性所見を認めたのはわずか 2 例 (10.5\%) にすぎない，われわれも13耳中 1 耳に Hennebert 症候を認めたのみであり，少なくとも本 邦の報告例では Hennebert 症候の 発現頻度 は高くないと思われる。外リンパ瘦における Hennebert 症候の発現機序として, 暁らは内 耳膜に破綻があると負荷された外耳圧に対する 緩衝作用の欠如により，外耳からの圧刺激が直 接内耳に伝わり内耳液の流動を引きおこすと推 論しているが，どの程度の内耳空破裂で，どの 程度の外耳圧負荷がかかった場合に陽性となる のかは今後の課題であると述べている. 自発, 
頭位眼振は高頻度にみられ，特に患側を下にす ると増強するといわれているが，深谷ら4) の報 告ではそう高頻度にはみられていない。また Shelton ら, Seltzer らの報告には記載がないが, われわれの結果では最も多くみられており，や はり重要な示標であると思われる.

聴力型: Shelton らが述べているごとく，ど の報告も一定の聴力型を認めない，外リンパ瘻 に特有の聴力型はないように思われる。一方， 渋谷ら ${ }^{100}$ の報告によれば仰臥位で聴力が改善す る場合があるという。

めまいの予後：どの報告例屯非常に良好であ る. 改善率は $90 \%$ 以上である. めまいの予後は 明らかに良好といえる。 ENG 下に眼振がみら れてあ自覚的にはめまいは軽快ないし消失する 場合がほとんどで，平衡機能に関してはすみ やかに代償作用が働くものと思われる。しかし ENG 下に眼振がみられるととは，末梢前庭系 には障害が残存していることであり，乙の観点 からは，聴力の予後と大差はないように思わ れる。

聴力の予後：改善率は Seltzer らの報告で約 50\%，われわれの報告（非手術例を含む）では 46.1\%の改善率であった。ここで注意しなけれ ばならないのは，保存的に治療した場合と手術 を施行した場合でどの程度予後に差が出るかと いう点であろう。われわれの結果では手術例と 非手術例之の間に聴力改善の有意差はみられず, また悪化例についても手術例で 1 耳(20\%)，非 手術例でも 1 耳（12.5\%）と有意差はみられな かった。 これは Simmons ${ }^{11)}$ の提唱する二重膜 破裂説によれば，膜迷路の障害が聴力の予後を 決定する最大の要因であり，手術では内耳空の 閉鎖のみが可能で，膜迷路の損傷に対しては直 接の修復を行えない，そのため手術の有無と聴 力の予後とは必ずしあ相関しない屯のと考えら れる. しかし，手術の必要性については，(1)外 リンパ瘻の確定診断は手術によってのみ可能で ある，(2)少なくとあ内耳空の閉鎖が可能である， (3)手術の有無と聴力の悪化との間に相関がない
ことから，診断，治療の両面において積極的に 行うべきと思われる．深谷ら ${ }^{81}$ ，新川ら ${ }^{12)}$ も， 従来の保存的療法では難治であった突発性難聴, 変動性感音難聴などの中に外りンパ瘦が存在し, 手術により完治，改善させることが出来るため 内耳空閉鎖術を積極的に行うべきであると述へ ている．また中島ら ${ }^{13)}$ は無症候性の外リンパ瘦 (silent fistula) が起こり得ることを報告してい るが，乙の場合，確定診断は手術によってのみ 可能である．乙れらのととから，手術により明 確に外リンパ瘻を診断，治療するととで疾患概 念を定着させることが肝要と思われる.

\section{まとめ}

1）新潟大学耳鼻咽喉科で経験した外リンパ 瘻12例（13耳）について検討を加えた.

2 ）原因は気圧変動によるものが多かった.

3 ）発症時の症状は聴力障害が最も多く，つ いでめまいが多かった４４例（33.3\%）はめま いと聴力障害が共に認められた。明確な pop 音はみられなかった。

4 ) 平衡機能検査では, 方向固定性頭位眼 振が最も多く，ついで CP が多くみられた。 Hennebert 症候は 1 例のみにみられた。

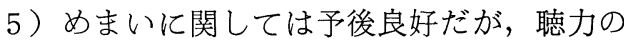
予後は症例によりさまざまであった。

6 ）手術の有無と予後の間には相関はみられ なかった。

7 ）乙れらの集計結果と他の報告とを比較す ると，他の報告例では外リンパ瘻はより広範な 年歯層に出現しており，原因として特発性のも のが多かった。

\section{参考文献}

1) Simmons FB: Theory of membrane breaks in sudden hearing loss. Arch Otolaryngol 88 : 67〜74, 1968.

2) Fee GA : Traumatic perilymph fistulas. Arch Otolaryngol $88: 477 \sim 480,1968$.

3 ) 寺山吉彦 : 外リンパ瘻をどのような時疑うか. JOHNS $1:$ 58〜 62, 1985.

4) 深谷 卓, 野村恭也 : 外リンパ瘻の臨床像一文献 
的考察一. 耳喉 $57: 271 \sim 278,1985$.

5 ) Seltzer $\mathrm{S}$ and McCabe BF : Perilymph fistula; the Iowa experience. Laryngoscope $96: 37 \sim 49$, 1986.

6 ) Shelton C and Simmons FB : Perilymph fistula ; the Stanford experience. Ann Otol Rhinol Laryngol $97:$ 105 108, 1988.

7 ）中野雄一, 細川 智 : 突発性難聴が疑われた気圧 性外傷の 2 例. 耳喉 $48: 669 \sim 673,1976$.

8 ）深谷 卓, 野村恭也：聴力障害を欠く外リンパ瘦 症例一試験鼓室開放術の適応拡大についての提 案一. 耳鼻臨床 $78: 1389 \sim 1392 ， 1985$.

9 ）暁 清文, 佐伯忠彦, 西原信成：外傷性めまい症 例における外リンパ㿉の検討. Equilibrium Res $46: 160 \sim 163,1987$.

10）渋谷知子, 麻生 伸，水越鉄理：体位変化により
聴力変動を示した外りンパ瘦が疑われた 5 症例. 耳喉頭頸 $60: 995 \sim 1000,1988$.

11) Simmons FB: The double-membrane break syndrome in sudden hearing loss. Laryngoscope $89: 59 \sim 66,1979$.

12）新川 敦, 坂井 真, 三宅浩郷 : 高度先進医療(1) 内耳空閉鎖術. 耳喉頭頸 $60: 1055 \sim 1060 ， 1988$.

13）中島 務, 荒尾はるみ, 渡辺祐介, 他: 内耳空破 裂症の臨床像一特にいわゆる “silent fistula” につ いて. 耳鼻臨床 $78 ：$ 1023 1026， 1985.

$$
\left(\begin{array}{l}
\text { 原稿受付 : 平成元年 } 6 \text { 月 } 26 \text { 日 } \\
\text { 原稿採択 : 平成元年 } 7 \text { 月 } 7 \text { 日 } \\
\text { 別刷請求先 : 五十嵐秀一 } \\
\text { 干951 新潟市旭町通 } 1 \text { 番町 } 757 \\
\text { 新潟大学医学部耳鼻咽喉科学教室 }
\end{array}\right)
$$

